\title{
Stakeholders Participation in Governing Indonesian Female Domestic Workers: Legal Problem Perspective
}

\author{
Lely Indah Mindarti ${ }^{1}$, Ali Maskur ${ }^{2 *}$ Siti Rochmah $^{3}$ \\ lelyindahmindarti@gmail.com ${ }^{1}$, alimaskur@ub.ac.id ${ }^{2}$ \\ *Corresponding author: Ali Maskur \\ Department of Public Administration, Universitas Brawijaya, Malang, Indonesia ${ }^{123}$
}

\begin{abstract}
Memorandum of Understanding (MoU) is an important component in ensuring and protecting the sustainability of Indonesian female domestic workers in Malaysia. The absence of the MoU encourages the researchers to conduct further investigation. Therefore, this study aims to describe the process of the agreement and the step that was conducted as well as the actors involved to the agreement process. In addition, this study also aims to analyze the cause affecting the absence. The study relied heavily on qualitative research method. Consequently, the data were generated from semi-structure interview and documentation. Ministry of Manpower and National Agency of Placement and Protection of Indonesian Worker were the main respondents of this study.
\end{abstract}

Keywords: female domestic workers, memorandum of understanding, Indonesia, Malaysia, gender participation.

\section{Introduction}

The globalization which is getting stronger have resulted in increasingly vague distances between regions. It increased social movement across countries. It also stimulated the global attention (such as UN, ILO, IMF, World Bank, OECD, etc) toward global migration. As a matter of fact, the ILO specially showed its concern for workers' movement by providing social protection to the workers. It was quoted in the ILO's Decent Work Agenda. The third objective of the Agenda is to extend social protection by promoting "both inclusion and productivity by insuring that women and men enjoy working condition that are safe, allow adequate free time and rest, take into account family and social values, provide for adequate compensation in case of lost or reduce income and permit access to adequate health care". In addition, the establishment of ASEAN Economic Community (AEC) in 2007 also increased the enthusiasm of the Southeast Asia community to move across border. Moreover, the AEC established ASEAN as a single market and transform ASEAN into region with free movement of goods, services, investment, skilled labour, and capital. It gave impact to the ability of society in accessing employment. Ministry of Manpower noted that there was an increase in the number of Indonesian Migrant Workers from 234.451 people in 2016 toward 262.899 people in 2017. Of these, more than $54 \%$ of them work in the informal sector. When compared to other types of work, housemaids are the type of work that dominates Indonesian Migrant Workers. Most of the migrant worker were dominated by female migrant workers. In 2017, it 
was noted that more than $70 \%$ of the total migrant worker were female [1]. This shows that the number of female migrant worker is much higher compared when compared to male. The gap between male and female is higher by time the time. Most of the works in informal sector namely housemaid.

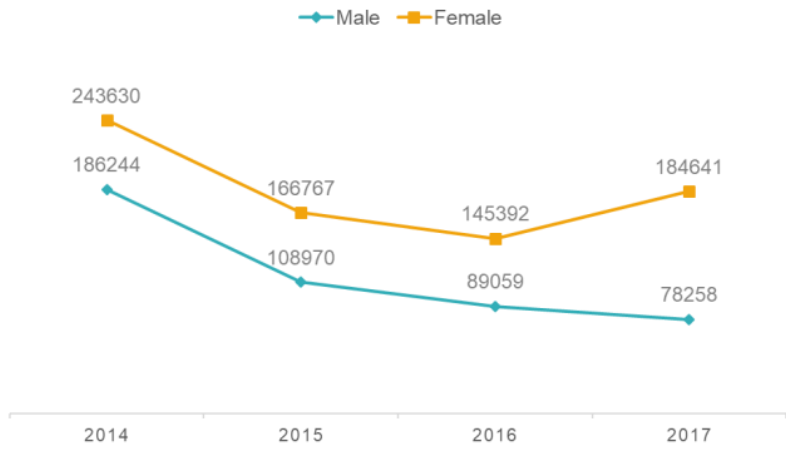

Fig. 1. Number of Indonesian Migrant Worker based on Gender

This condition has resulted female migrant workers being more vulnerable to problems. Moreover, most of them have low level of education. It affects to the lack of knowledge and their ability to avoid problems.

Therefore, there needs to be legal clarity that can protect the female migrant worker. The purpose of law or policy is to provide security guarantees and control migrant workers from various negative impacts [2]. One form that can apply and regulate is through establishment of a Memorandum of Understanding $(\mathrm{MoU})$. The existence of a $\mathrm{MoU}$ is very important in minimizing the negative impact on female migrant workers. the absence of legal clarity will cause many negative effects such as vulnerability to various forms of discrimination, violence and abuse, even violations of human rights [3] [4].

However, the MoU regulating migrant worker has expired since May 2016. This is a major obstacle to protecting migrant worker in Malaysia. In fact, even though the MoU is available, mogrant worker still obtain limited law protection. Nevertheless, the MoU is an important part in protecting Indonesian workers.

Therefore, is is important to identify various things that have resulted in the difficulty of reaching an agreement to formulate MoU between Malaysia and Indonesia. Many studies have attempted to identify legal frmaeworks for the protection of migrant workers, but researchers have yet to find reseacrh that attemps to examine the various possibilities of the difficulty of an agreement between Malaysia and Indonesia regarding Indonesia Migrant Worker. In fact, this phenomena occurred in 2011 and did not rule out the possibility of future accurrences.

The result this study will greatly assist the government in both countries in understanding various things that hinder the information of the MoU so that they are able to anticipate various possible obstacles that will arise. In addition, this study will also provide an overview to Indonesian Migrant worker regarding the process of drafting then MoU so that they are more aware of the preparation and actively participate in providing input to the government in the process of drafting the MoU. 


\section{Research Method}

This research was conducted by using qualitative research method. Therefore, the data were generated form semi-structure interview and documentation. The interview conducted to the two responsible governmental office, namely: Ministry of Manpower of the Republic of Indonesia and National Agency of Placement and Protection of Indonesian Worker. It due to the responsibility of those institution in managing Indonesian Migrant Worker. The informants of this study are Director of Placement and Protection of Migrant Worker and Head of National Agency of Placement and Protection of Indonesian Worker. While documentary data was generated for existing document such as: profile of Indonesian Migrant Worker, profile of Female Domestic Worker, the Act Number 39/2014, the Act Number 18/2017, and so on.

\section{Result and Discusion}

A Memorandum of Understanding is an agreement entered into by two parties to negotiate in order to make an agreement at a later date. Under Act No. 39/2004, which was amended to Act No. 18/2017, the Indonesian government entered into bilateral trade agreement with Malaysia government regarding Indonesian Migrant Worker. It is conducted in order to guarantee the rights of migrant workers and protect them from various negative impacts. However, along with the expiration of the agreement between the two countries, Indonesian Migrant Worker in Malaysia does not have strong legal entity to protect. Below will be discussed about several things related to the agreement.

\subsection{Process of MoU}

Toward the end of the Indonesia-Malaysia MoU related to Indonesian Migrant Worker, the governments of the two countries have actually reached an agreement to work together to place Indonesian Migrant Worker in Malaysia through a single channel system. The channel system was implemented based on a system that is connected between the two counties. In this channel system, labour market information was exchanged, especially regarding job vacancies and Indonesian Migrant Worker candidate profile. The agreement took place at a bilateral meeting between Indonesia and Malaysia at the Putrajaya International Convention Center (PICC) Malaysia on September 23, 2016. The agreement was written in a Letter of Intent (LoI) signed by the Minister of Manpower of Republic of Indonesia and Malaysian Minister of Human Resources. The bilateral meeting was a follow-up to the talks between Indonesian President Joko Widodo and Malaysian Prime Minister Abdullah Najib at the time.

Based on the description above, it can be concluded that the actual effort to extend the MoU was initiated in 2016. However, after the MoU ended in May 2016 there has been no significant progress. Based on the statement of the ministry Manpower, the Malaysian Government has responded to the MoU request sent by Indonesia. However, the Malaysian government is considered less serious or less committed in following up on the MoU drafting process.

MoU between Indonesia and Malaysia must be ratified to continue cooperation in terms of sending Indonesian workers to Malaysia. The agreement process (MoU) between Indonesia and Malaysia must go through several stages before it can be implemented. These stages are negotiation, signature, and ratification. 


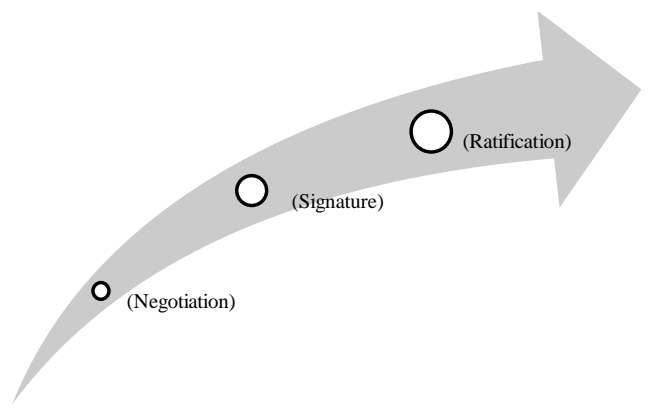

Fig. 2. Process of MoU

The negotiation process must be carried out by both countries, namely Indonesia and Malaysia. However, until now, the negotiation process has not been carried out because the Malaysian government is considered not serious to enter into an agreement. The draft agreement that was sent by the Government of the Republic of Indonesia in November 2016 has not received a reply from the Malaysian Government. The Malaysian government considers that there are several articles in the draft agreement that burden the Malaysian Government. These articles relate to the cost of placing Indonesian workers, the minimum salary of Indonesian workers, and the specialization of Indonesian workforce.

\subsection{The Involving Actors in Drafting MoU}

Legislation has mandated that efforts to protect and place Indonesian Migrant Workers must be carried out in an orderly, efficient and effective manner to improve human, national and state dignity. This was done to improve the welfare of the workforce, the expansion of employment opportunities which in turn would have an impact on increasing foreign exchange revenues. Therefore, in its efforts to improve protection of Indonesian Migrant Workers, changes to the Law relating to Indonesian Migrant Workers are made, namely from Act No. 39 of 2004 concerning the Placement and Protection of Indonesian Workers Abroad was changed to Act No. 18 of 2017 concerning Protection of Indonesian Migrant Workers. Act No. 18 of 2017 was ratified on November 22, 2017.

The establishment of Act No. 18 of 2017 brought changes to the mention of citizens working abroad who were originally Indonesian Migrant Workers. The changes were made because of the negative stigma of Indonesian labor migrants that is identical to lower middle class workers. The change in naming was expected to reduce the negative stigma that exists in the community. In addition, this naming change also shows the desire of the Indonesian government to change the sending of workers who were formerly unskilled workers to skilled and educated workers.

In addition, the establishment of Act No. 18 of 2017 also shows the government's efforts to improve the protection of Indonesian Migrant Workers. There are seven crucial issues in the new act, namely:

- Institutional reform. This act clarified the institutional functions of the government so that it is expected that there will be no overlapping of tasks and functions. There were 2 institutions that handle the Indonesian Migrant Worker, namely: The Ministry of Manpower and the National Agency for the Placement and Protection of Indonesian 
Workers (NAPPIW). The new act distinguished the roles of each institution in which the Ministry of Manpower was the regulator while NAPPIW was the operator.

- The role of government was greater when compared to the private sector. The private sector only had the role of providing information about employment abroad.

- Establishment of a One-Stop Integrated Institution (OSII) which would be the service center of all Indonesian Migrant Worker. OSII also had the authority to approve or reject the sending of Indonesian Migrant Worker to the destination country. Therefore, Indonesian Migrant Worker shipments must be recorded at OSII.

- Vocational training and empowerment by Vocational Training Centers (VTC).

- Indonesian Migrant Worker Placement Companies must coordinate and request permission from OSII to send Indonesian Migrant Worker abroad.

- Indonesian Migrant Worker's social security was entrusted to the Social Security Administrator for employment.

- Indonesian Migrant Worker's fees were no longer charged to workers, but are charged to prospective employers

From the seven issues, it could be seen that there were government efforts to improve protection for Indonesian Migrant Worker, especially at point 7. In addition, the government's seriousness in Indonesian Migrant Worker protection efforts was also seen in the existence of specific Chapters and Articles concerning Protection of Migrant Workers, Rights Migrant Workers, Social Security, Duties and Responsibilities of Central and Regional Governments, One-Stop Integrated Services, and Protection of Indonesian Migrant Workers.

As a follow up to the establishment of Act No. 18 of 2017, several derivative regulations must be drafted as operational implementation of the new law. There were about 28 regulations that must be established, including: 11 Government Regulations, 12 Ministerial Regulations, 2 Presidential Regulations, and 3 Regulations of the Head of the Agency. However, until now, the derivative regulations have not yet been established. Therefore, the previous derivative regulation (the derivative regulation of Law No. 39 of 2004) was still used as the basis for managing Indonesian Migrant Worker.

Foreign policy of a country is an extension of domestic politics. Therefore, even domestic politics can be used as one level of analysis in analyzing foreign policy, one of which is the process of forming until the signing of the MoU. The importance of domestic politics in determining the foreign policy of a country is present when domestic politics causes the country to pursue suboptimal objectives of its foreign policy and when differences in political institutions of a country, economy, and leadership goals which are not related to relative power can explain choices related to foreign policy. This indicates that the formation of foreign policy is influenced by the involvement of institutions.

Changes in legislation - as explained above - greatly influenced the preparation of the MoU. In addition, a change in the role of Indonesian Migrant Worker management between the Ministry of Manpower and NAPPIW also affected the pattern of relations between actors in the preparation of the MoU. In the process of drafting the MoU, there were at least a number of actors who should be involved and involved that consist of the Government, Private Sector, Indonesian Migrant Worker Representatives, and NGOs. There were several government actors who have a central role in the formation of the MoU, namely: the Ministry of Foreign Affairs, the Ministry of Manpower, and NAPPIW. While the private sector was the Indonesian Migrant Worker Placement Company. Currently there were 477 Indonesian Migrant Worker Placement Companies spread throughout Indonesia.

During this time the MoU was signed by representatives from Indonesia and Malaysia where Indonesia represented by the Minister of Manpower and from Malaysia was represented 
by the Minister of Human Resources. In addition to the two ministers from both countries, there were also other actors from Indonesia, namely the Ministry of Foreign Affairs and NAPPIW Non-Departmental Government Institutions in Indonesia who have the function of implementing policies in the field of placement and protection of Indonesian Workers abroad in a coordinated and integrated manner.

\subsection{Obstacles in the Process of Drafting MoU}

The formulation of MoU between Indonesia and Malaysia did not run smoothly. There were several obstacles in the formulation of MoU. Even though the MoU was very important to ensure maximum benefits by providing protection for Indonesian Migrant Workers in Malaysia. Therefore, the Indonesian Government wanted a change in the MoU related to the rights and protection of Indonesian Migrant Workers. However, the Malaysian Government had not approved the draft of agreement that had been sent by the Indonesian Government. Both Indonesian and Malaysian Government could not agree regarding the basic salary of Indonesian Migrant Workers in Malaysia.

Another thing that was considered by the Malaysian Government was the cost that must be incurred by the Malaysian Government during the process of placing the Indonesian Migrant Workers. This was based on Act Number 18 of 2017 which stated that all of these costs are not charged to Indonesian migrant workers, but to prospective employers, namely Malaysia. This meant that Malaysian citizens would employ Indonesian migrant workers who had to bear the costs.

In addition, the political situation also affected the process of negotiations related to the MoU. The holding of elections for the prime minister's election in Malaysia forced the Malaysian government to focus more on holding elections. The election results also resulted in changes in Malaysian government policies and structures. Previously, the Indonesian government had established communication with the Malaysian government during Prime Minister Dato 'Sri Mohd Najib Tun Abdul Razak's leadership and had agreed to follow up to the next stage. Change in leadership from Dato 'Sri Mohd Najib Tun Abdul Razak to Tun Dr Mahathir Mohamad resulted in the government in the two countries had to carry out communication again in connection with the final results of the MoU discussion during the Dato' Sri Mohd Najib Tun Abdul Razak administration.

In addition to Malaysia's political conditions, Indonesia's political conditions had also greatly influenced the Indonesian government's strategy to urge the Malaysian government to be more serious about formulating an MoU. Indonesia will hold a presidential election in 2019. In the election, President Joko Widodo also nominates as a presidential candidate. This would more or less influence government policy to force the Malaysian government. The strategy that could be used by the Indonesian government was to conduct a moratorium on the sending of migrant workers to Malaysia. However, for the Joko Widodo administration, this was a difficult decision. On the one hand, the moratorium would be able to urge the Malaysian government to be more serious with the establishment of a MoU, given the country's high dependence on Indonesian migrant workers. Figure 4 illustrates that the number of Indonesian workers in Malaysia is the highest compared to other countries. 


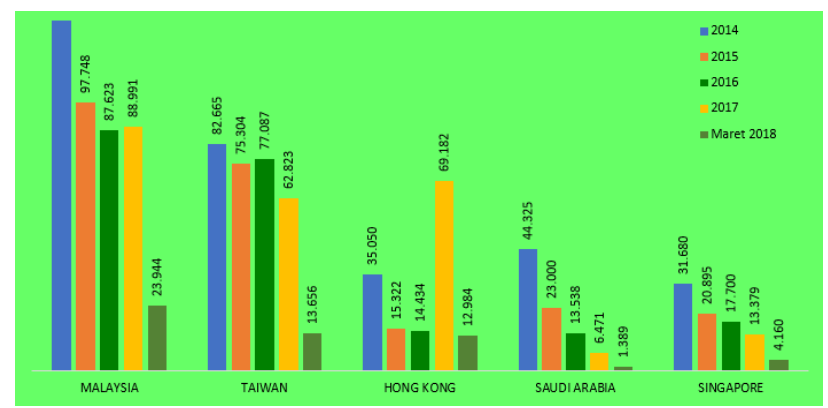

Fig. 3. Placement of Indonesian Migrant Worker

However, on the other hand, if the Indonesian government decided to carry out a moratorium, it would increase the number of illegal Indonesian migrant workers. This was because it was very difficult to prevent people from working in Malaysia. Therefore, if the government conducted a moratorium, it would have the potential to reduce the electability of Joko Widodo's election in the 2019 election. The issue of illegal Indonesian migrant workers would be an issue that could reduce his electability.

\subsection{Strategic for Achieving MoU}

In order to encourage Malaysian Government in approving Memorandum of Understanding (MoU), Indonesia Government had prepared several strategic action to be conducted. First, Indonesian Government agreed to implement moratorium. Indonesian Government would stop sending Indonesian Migrant Workers to Malaysia until the Malaysian Government agreed and responded the requirement of Indonesian Government to renew the Memorandum of Understanding (MoU). Memorandum of Understanding (MoU) could give opportunities to Malaysian and Indonesian Government to correct and improve standard and procedures of Indonesian Migrant Workers handling, especially in term of protection. Moratorium would give impact to employment activities in Malaysia. This was because Malaysia had high dependency toward Indonesia, especially related to employee availability. Moreover, most of Malaysian worker came from Indonesia.

Moratorium in one side had potential in giving negative impact toward employment condition in Indonesia, especially related to reduction of the number of unemployment in Indonesia. This required the Indonesian Government to be able to provide domestic jobs. In addition, the moratorium also had the potential to increase the number of Indonesian illegal migrant workers. This could happen if the Indonesian Government unable to provide jobs for prospective workers.

The lack of jobs opportunities abroad (do to the moratorium) would also affect the public's trust toward the Indonesian Government. This would greatly affect the electability of Joko Widodo in the 2019 elections. Historically, the Moratorium was once carried out by the Indonesian Government against sending Indonesian Migrant Workers to Malaysia in 2009 which proved successful to pressure the Malaysian Government to sign the MoU in 2011. However, the moratorium was not an approach that could be done time to time. If the level of the Malaysian Government's dependency toward Indonesian Migrant Workers decreased, the implementation of Moratorium strategy would not be effective anymore to pressure the Malaysian Government to agree and sign the MoU. 


\section{Conclusion}

MoU was quite significant for Indonesian Migrant Worker protection. There were three steps in the agreement including negotiation, signature, and ratification. Currently, the step was stagnant in the negotiation. The lack of synergy between domestic actors becomes obstacle to the agreement. Moratorium could be an alternative solution in overcoming the problem. Even though, this solution run effectively in 2011, but it will not effective forever.

\section{References}

[1] M. o. M. o. T. R. o. Indonesia, "Data of migrant worker of Indonesia," June 2018. [Online]. Available: http://kemnaker.go.id/data-pmi. [Accessed 26 August 2018].

[2] H. B. Lasimbang, W. T. Tong and W. Y. Low, "Migrant workers in Sabah, East Malaysia: The importance of legislation and policy to uphold equity on sexual and reproductive health and rights," Best Practice \& Research Clinical Obstetrics \& Gynaecology, vol. 32, pp. 113-123, 2016.

[3] Purwowibowo, "Woman migrant workers and social protection systems in the Philippines," Journal Sampurasun, vol. 03, pp. 23-31, 2017.

[4] D. Rahayu, "Is the state of Indonesia in charge to provide law protection to the Indonesian Migrant workers?," Journal of Physics: Conference Series, vol. 953, pp. 1-6, 2018. 